\title{
Katz among the Pigeons: The Erosion of the Fourth Amendment of the Constitution of the United States of America
}

\author{
G. E. Minchin \\ Barrister and Solicitor of the High Court of NZ, New Zealand \\ Email: graeme@minchin.nz
}

How to cite this paper: Minchin, G. E. (2020). Katz among the Pigeons: The Erosion of the Fourth Amendment of the Constitution of the United States of America. Beijing Law Review, 11, 561-578. https://doi.org/10.4236/blr.2020.112034

Received: April 21, 2020

Accepted: May 25, 2020

Published: May 28, 2020

Copyright $\odot 2020$ by author(s) and Scientific Research Publishing Inc. This work is licensed under the Creative Commons Attribution International License (CC BY 4.0).

http://creativecommons.org/licenses/by/4.0/

\begin{abstract}
In Katz v. United States the Supreme Court of the United States considered Fourth Amendment rights. This decision is seen as bolstering rights, as it rolled back previous decisions which restricted the scope of the Fourth Amendment. However, it did so by conceptualising the Fourth Amendment as a right to privacy when the text of the Amendment states it is to protect "the right of the people to be secure...". This re-writing of the Fourth Amendment reduced a public "right of the people", which reflects the broad societal perspective, to a merely personal right or interest. The Right was given broader scope but it was made weaker. In most circumstances a personal interest will be trumped by a public interest, such as law and order, because the latter will engage the interests of more people. What is lost is the public interest in restraining state power.
\end{abstract}

\section{Keywords}

Fourth Amendment, US $v$ Boyd, Katz $v$ US

\section{Introduction}

The Fourth Amendment of the US Constitution provides:

The right of the people to be secure in their persons, houses, papers, and effects, against unreasonable searches and seizures, shall not be violated, and no Warrants shall issue, but upon probable cause, supported by Oath or affirmation, and particularly describing the place to be searched, and the persons or things to be seized.

Since 1967 the Fourth Amendment has largely borne the meaning given to it 
by the US Supreme court in Katz. In Katz the US Supreme Court interpreted the "right of the people" to be "secure" from "unreasonable search and seizures", as personal right to privacy. Katz has been generally seen as significantly expanding Fourth Amendment protections but the reverse is more correct. The scope of the Fourth Amendment was expanded, in relation to its being improperly read down in prior cases but the protections Katz significantly diminished. This is because conceptualised as a privacy right, the Fourth Amendment is shorn of its original intention, which was to provide security to the public, by restraining state power. In Katz Justice Brandeis interpreted the right to be secure as being a personal right to privacy. This is reductionism, in which the constitutional dimension is lost and liberty becomes a mere personal interest rather than a collective interest. By this interpretation "the people" referred to in the Fourth Amendment was conceptualised as being the plural of person, as privacy is a personal interest, whereas properly the Fourth Amendment's reference to "the people" denotes a collective public right. The conceptualisation of rights as public interest, which is necessarily possessed by individuals, is the classical and correct conceptualisation, as set out by Lord Coleridge in Bonnard v Perryman:

The right of free speech is one which is in the public interest that individuals should possess.

Following Katz, what is lost is the public interest in restraining state power. In most circumstances a personal right will be trumped by a public right, such as the right to law and order, because public rights engage the interests of more people. While rights are generally validated by stressing the iniquity of individual oppression, of more moment is that state overreach can lead to the decay and collapse of society.

In 2012 the majority of the US Supreme Court in United States V. Jones, did hold that the placing of a tracking device on a vehicle fell to be considered in terms of the traditional Fourth Amendment analysis, under the law of trespass, rather than privacy expectations. What Jones did not do was to go beneath trespass as a value, to consider what social benefit was in play. The law of trespass can be conceptualised as either protecting security or privacy. In this paper it is argued that the conceptualisation of the right as being grounded in privacy is a derogation, as privacy is a less important value than security. Moreover, Jones did not engage in a discourse which considered privacy as an individual interest, in contrast to the collective, public interest, embodied in the "right of the people to be secure" as guaranteed by the Fourth Amendment. Further, there was no critique in Jones of privacy being the value in play where searches did not involve a physical trespass. This is a vital issue, as in the digital age searches and seizures are increasingly unable to be characterised as classical trespasses.

This paper focuses on Boyd v. United States in which the US Supreme Court struck down legislation in violation of the Fourth Amendment. In Boyd the Court considered in detail the historical context of the formulation of the Fourth Amendment so as to understand its purpose. The Court in Boyd looked first to 
the historical American context and then to the English context, through its discussion of Wilkes $v$ Wood. This paper then looks at the broader context again, to gain a better understanding of the values in play and expands on that contextual enquiry by discussing Entick $v$ Carrington, which preceded Wilkes and was the lead case. The thesis presented here is that the historic context and the English cases upon which the Court in Boyd indicates that the Fourth Amendment was founded on, demonstrate that privacy was never considered to be the underlying value at issue. Rather the core concern was that State action without limitation by law threatened to "destroy all the comforts of society" use the language of Pratt CJ in Entick v Carrington.

This is part one of a projected three-part analysis of the descent of the Fourth Amendment by which a core public "right of the people", to be secure from over-reaching state power, was reduced to a mere personal interest in one's privacy. The result of this is that colloquially the Fourth Amendment is now known as "the incredible shrinking Fourth Amendment". In the proposed second part there will first be an analysis of Hester V. United States, and Olmstead v United States, both prohibition cases, in which the Court drastically read down the Fourth Amendment, in abject deference to the state enforcement of morality. It is noted that contrary to Stare Decisis, Hester and Olmstead fail to refute or even engage with the Court's reasoning in Boyd. The third part will focus on Katz itself and subsequent case law. In contrast to the constitutional and historical analysis exemplified in Boyd, Hester is characterised by judicial error, Olmstead by judicial deference and Katz by judicial creativity.

\section{Boyd v. United States}

In Boyd the Court considered the constitutionality of an Act of Congress, the relevant section being described as follows:

The 6th section of the act of June 22, 1874, entitled "An act to amend the customs revenue laws", \&c., which section authorizes a court of the United States, in revenue cases, on motion of the government attorney, to require the defendant or claimant to produce in court his private books, invoice and papers, or else the allegations of the attorney to be taken as confessed: ${ }^{2}$

The decision of the Court, given by Justice Bradley, struck down the legislation as unconstitutional finding:

It is true that certain aggravating incidents of actual search and seizure, such as forcible entry into a man's house and searching amongst his papers, are wanting, ... but ... a compulsory production of a man's private papers to establish a criminal charge against him, or to forfeit his property, is within the scope of the Fourth Amendment to the Constitution in all cases in which a search and seizure would be, because it is a material ingredient,

${ }^{1}$ Entick v Carrington. 818.

${ }^{2}$ Boyd v. United States 116 U. S. 616. 
and effects the sole object and purpose of search and seizure. ${ }^{3}$

It is salient that in coming to its decision the Court rejected "any long usage or a contemporary construction of the Constitution which would justify any of the acts of Congress now under consideration". "The Court noted that the common law authorised the seizure of stolen goods and that English statute had authorized seizure of prohibited goods or goods tax was owed on for the past 200 years. Comparing such statutes with early American legislation the Court stated that:

The first statute passed by Congress to regulate the collection of duties, the act of July 31,1789, 1 Stat. 29, 43, contains provisions to this effect. As this act was passed by the same Congress which proposed for adoption the original amendments to the Constitution, it is clear that the members of that body did not regard searches and seizures of this kind as "unreasonable", and they are not embraced within the prohibition of the amendment. ${ }^{5}$

Distinguishing search and seizure for the above purposes the Court held that:

The search for and seizure of stolen or forfeited goods, or goods liable to duties and concealed to avoid the payment thereof, are totally different things from a search for and seizure of a man's private books and papers for the purpose of obtaining information therein contained, or of using them as evidence against him. The two things differ toto coelo. In the one case, the government is entitled to the possession of the property; in the other it is not. $^{6}$

In construing the Act to be unconstitutional the Court looked at the context within which the Fourth Amendment was formulated stating:

In order to ascertain the nature of the proceedings intended by the Fourth Amendment to the Constitution under the terms "unreasonable searches and seizures", it is only necessary to recall the contemporary or then recent history of the controversies on the subject, both in this country and in England. The practice had obtained in the colonies of issuing writs of assistance to the revenue officers, empowering them, in their discretion, to search suspected places for smuggled goods, which James Otis pronounced:

"the worst instrument of arbitrary power, the most destructive of English liberty, and the fundamental principles of law, that ever was found in an English law book;" since they placed "the liberty of every man in the hands of every petty officer." This was in February, 1761, in Boston, and the famous debate in which it occurred was perhaps the most prominent event which inaugurated the resistance of the colonies to the oppressions of the mother country. "Then 
and there," said John Adams:

"then and there was the first scene of the first act of opposition to the arbitrary claims of Great Britain. Then and there, the child Independence was born."

Continuing to reference historic context the Court then related English matters which were "were fresh in the memories of those who achieved our inde-

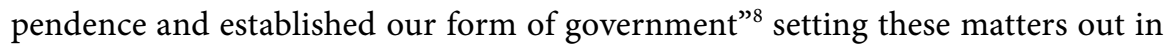
detail, as follows:

In the period from 1762, when the North Briton was started by John Wilkes, to April, 1766, when the House of Commons passed resolutions condemnatory of general warrants, whether for the seizure of persons or papers, occurred the bitter controversy between the English government and Wilkes, in which the latter appeared as the champion of popular rights, and was, indeed, the pioneer in the contest which resulted in the abolition of some grievous abuses which had gradually crept into the administration of public affairs. Prominent and principal among these was the practice of issuing general warrants by the Secretary of State for searching private houses for the discovery and seizure of books and papers that might be used to convict their owner of the charge of libel. ${ }^{9}$

In stating its opinion, the Court held:

It does not require actual entry upon premises and search for and seizure of papers to constitute an unreasonable search and seizure within the meaning of the Fourth Amendment; a compulsory production of a party's private books and papers to be used against himself or his property in a criminal or penal proceeding, or for a forfeiture, is within the spirit and meaning of the Amendment.

It is equivalent to a compulsory production of papers to make the nonproduction of them a confession of the allegations which it is pretended they will prove.

A proceeding to forfeit a person's goods for an offence against the laws, though civil in form, and whether in rem or in personam, is a "criminal case" within the meaning of that part of the Fifth Amendment which declares that no person "shall be compelled, in any criminal case, to be a witness against himself".

The seizure or compulsory production of a man's private papers to be used in evidence against him is equivalent to compelling him to be a witness against himself, and, in a prosecution for a crime, penalty or forfeiture, is equally within the prohibition of the Fifth Amendment.

Both amendments relate to the personal security of the citizen. They nearly 
run into, and mutually throw light upon, each other. When the thing forbidden in the Fifth Amendment, namely, compelling a man to be a witness against himself, is the object of a search and seizure of his private papers, it is an "unreasonable search and seizure" within the Fourth Amendment.

Constitutional provision for the security of person and property should be liberally construed. ${ }^{10}$

Boyd is a paradigm constitutional case. It uses the actual words of the Fourth Amendment and throughout. It appears from the passage of the Court's decision referred to above in which "long usage" and a "contemporary construction of the Constitution" were raised, that the court was invited by the Federal attorney arguing the case to adopt a contemporary construction of the Constitution. If this was the case, such an approach was emphatically rejected, the Court juxtaposing that reference to its observation that: "Even the act under which the obnoxious writs of assistance were issued did not go as far as this"11. Rather than adopting a "contemporary construction" as sought by counsel for the US, the Court in Boyd embarked upon a detailed historical and contextual construction of the Fourth Amendment, liberally quoting from James Otis and John Adams ${ }^{12}$.

In setting out the case the Court says that it involves a "very grave question of constitutional law, involving the personal security, and privileges and immunities of the citizen"13. The word "citizen", though necessarily denoting the singular, refers not to individuality but to a membership of political society, which here is membership of the Republic. In addition to the reference to "personal security", as guaranteed by the Fourth Amendment and the use of the terms "privileges and immunities" directly refers to the power dynamic between citizens and state. It is for this reason that the court in Boyd states "Constitutional provision for the security of person and property should be liberally construed."

Moving from the general "liberty of the subject" as a constitutional right Otis applied this to the extant situation, also referencing Semaynes Case, as follows:

Now one of the most essential branches of English liberty, is the freedom of one's house. A man's house is his castle; and while he is quiet, he is as well guarded as a prince in his castle. This writ, if it should be declared legal, would totally annihilate this privilege.

John Otis's influence on John Adams needs no discussion here and neither does Adam's role in the drafting of Art. XIV of Massachusetts Constitution of 1780 and subsequently the Fourth Amendment. The Fourth Amendment springs directly from Otis's constitutional discourse in the Writ of Assistance Case. In this famous case, as in Boyd, there is no reference to privacy as the value or even a value, which grounds the right of the people to be secure from unlawful search

\footnotetext{
${ }^{10}$ Ibid 616:617.

${ }^{11}$ Ibid 623.

${ }^{12}$ Ibid 625

${ }^{13}$ Ibid 618.
} 
and seizure. The issues for both are the same, restraint of power to prevent absolutism. Constitutional law operates on the macro level of power not the micro level of personal privacy. Tellingly the Court in Boyd held that "actual search and seizure, such as forcible entry into a man's house and searching amongst his papers" was merely aggravating, as the focus of the Fourth Amendment was to create a fetter on the State, rather than a remedy for the individual.

In Boyd the Court carefully elaborated the context in which the Fourth Amendment was written and sets out in detail the ideas and occurrences which informed the minds of the framers of the Constitution. The historical context the Court considered was not merely the American context but also the wider political context, which embraced the English dimension. Accordingly, in Boyd the Court referred to and applied the 1763 English case of Wilkes $v$ Wood. When speaking of John Wilkes, the Court stated that he was the "champion of popular rights, and was, indeed, the pioneer in the contest which resulted in the abolition of some grievous abuses which had gradually crept into the administration of public affairs" ${ }^{14}$. In order to understand this phrase, it is necessary to look at the broader historical contest in England, in which "...grievous abuses had gradually crept into the administration of public affairs" and the "contest" which arose.

\section{Historical Background to Wilkes v Wood}

In essence this paper is concerned with identifying the underlying social value which is expressed in the Fourth Amendment. The thesis here is that properly the social value at issue is public security from encroachment by the State, rather than personal privacy. Also in issue is how and why the value of public security has devolved into a lessor value, a mere interest in one's own personal privacy. To track this process, it is necessary to look at the related values in English society, which were contemporaneous to the origin of the common law defence against unreasonable search and seizure. To do this one must look closely at the nature of English society in this period to understand the historic context.

In regard to the "grievous abuses" the Court in Boyd was referencing the wholesale corruption of the English Parliament by King George III's Administration, which in part was made possible by the taxation of the American colonies without parliamentary representation. Besides income from the East India Company the ability of the Administration to bribe the majority of Parliament was largely dependent on taxes raised in America.

The "contest" referred to was the contest between the Administration and Constitutionalists, both in England and in America, who saw the wholesale corruption of Parliament as a collapse of the separation of powers. A central feature of this contest was the publication of critiques of this corruption, such as those by John Wilkes, to a highly engaged mass audience. At law this generated a contest between the English constitutional right to free speech and the law of sedi${ }^{14}$ Ibid 625. 
tious libel. This contest in turn led to a struggle over the extent of the power of the Administration to search for allegedly seditious libels. Prior to the period at issue the ability of the English government to enter person's homes had been constrained by Semaynes Case, where the encroachment of the liberty of the subject, by homes being broken into by the Sheriff, was held to be a trespass. This was an upholding of the limitation of the powers by the Crown by the Court. It is wrongly seen as the basis for the principle that "a man's home is his castle", but it is actually an affirmation of the liberty of the subject, within the balance of power in English society. The case is generally seen as being the legal authority for the requirement to knock before entry, but the basis for the finding by the Court was lack of lawful authority. Sir Edward Coke, in his Judgment stated:

...for without notice of the process of law and of the coming of the sheriff with the jury to execute it, the shutting of the door of his own house was lawful. ${ }^{15}$

However, by the mid 1700's, "notice of the process of law" had been eroded by the creeping application of general warrants, which did not articulate any specific offense and which ignored the presumption of innocence. Most importantly the role of the Judiciary to hold the Executive accountable to the rule of law, the core feature of the English separation of powers, was in abeyance. Without specificity in the warrant the Judiciary had no ability to properly gauge whether the likelihood that an offence had been committed out-weighted the presumption of innocence. These general warrants and in particular their formulation in the infamous Writs of Assistance, which were used to enforce England's economic stronghold over its American colonies, were a central grievance which led directly to the American War of Independence.

Because of the high status of freedom of speech in England at the time, these struggles were fought out within a broad societal context, which in turn generated the publication of numerous newspapers (Wardroper, 1973). The first daily was founded in London in 1702, 75 years before Paris could sustain one. By 1769 London supported:

six daily papers, eight evening papers published tri-weekly and numerous weeklies and monthlies. The American conflict helped to increase the number by 1783 to nine dailies and ten evenings. ... the provinces had a growing force of papers; about fifty as early as $1760 .^{16}$

The subscription base for these English newspapers was grounded in a widespread interest in political and public affairs. Johann von Archenholtz, a widely travelled German, commented on the broad interest in political discourse when he was in England:

One is sometimes dumbfounded to hear people of the meanest sort very se-

${ }^{15}$ (January 1st, 1604) 5 Coke Rep. 91.

${ }^{16}$ Wardroper 14. 
riously discussing laws, property rights, privileges etc. ... [o]ften nothing is more difficult than to make an Englishman converse; he replies to everything with a Yes or No; but if one has the address to start him off on politics, suddenly his face is alive, he opens his mouth, he becomes eloquent. ${ }^{17}$

The Swiss traveller, Cesar de Saussure, when in England in 1726 also reported:

All Englishmen are great newsmongers. Workmen habitually begin the day by going to coffee-rooms to read the latest news. I have often seen shoe-blacks and other persons of that class club together to buy a paper, Nothing is more entertaining than hearing persons of that class discussing politics and news about royalty ${ }^{18}$.

As discussed by Wardroper, the Administration's response to political engagement by the commoners was to tax newspapers out of their reach. While taxes limited sales, 3000 a day being a large circulation, "each overpriced copy was read by perhaps dozens; read or heard by hundreds in anxious times."19 Stamp duties and taxes eventually forced the price of a four-page newspaper up to seven-pence, or "nearly half a poor man's wage" ${ }^{\text {"20 }}$. The commoners response was to club together to afford the news.

Supported by an avid readership, it is in this period that the press fought for and won privileges and immunities which are now taken for granted. Previously reportage of the proceedings of the Houses of Parliament were declared "to be a breach of Privilege" ${ }^{21}$. John Wilkes "masterminded ... a showdown" and after riots and the Lord Mayor of London being sent to the Tower for refusing "to hand over the printers", ${ }^{22}$ Parliament capitulated. The Middlesex Journal wrote:

It matters not where a set of prostitutes may assemble... Though they should sit at Westminster, they are not a parliament if they sit and act in defiance of the inclinations of the people... The people would buy these publications ... see who were worthy to be returned to parliament, then we shall have an assembly fit to be so called. ${ }^{23}$

The struggle to reveal the workings of Parliament was driven by the public interest in the rampant corruption engendered by King George III's Administration. In 1769 the King ran up a debt of 513,000 pounds. Wardroper wrote:

... secret and special services, those items made up largely of political rewards, had absorbed (according to one surviving Treasury account) 630,000 pounds. ... In the Commons, Edmond Burke called it "a downright mockery" that they were asked to vote on the money without seeing any ac- 
counts. $^{24}$

Although opposition Members of Parliament, such as Edmond Burke, gathered together 135 MP's to vote for the production of accounts, 248 government supporters voted them down. In response The Political Register printed a mock King's speech [to Parliament];

You know that last winter there was only half a million of which I could not give an account. You had it among you; and that is enough to satisfy any reasonable man..$^{25}$

The political press also maintained a lively, explicit, condemnation of the affairs of royalty, which reflected the association of moral with political corruption and evidenced the Puritan element of the radical press. However, as John Almon's Political Register demonstrates, in regard to the King's Marriage Bill, introduced to prevent his progeny marrying commoners or Catholics, the press was often sardonic, rather than puritanical:

The Royal Marriage Bill has been passed at the expense of two British baronies, five Irish ditto, one advancement from ditto to an Irish Earldom, one blue ribbon [the Garter, for North], three red ones [the Bath], one baronetage, three revisionary patent places, 25,0001 in occasional gratuities, besides innumerable promises of lottery tickets. ${ }^{26}$

A variety of means were employed to control the press. Many newspapers were either owned by the political parties or provided with secret "pensions". Tory Prime Minister Pitt, had a stable of six tame newspapers, but the Whigs were not without their own influence. The Morning Post was convinced to stop assailing the Whig's ally, the Prince of Wales, and begun "denouncing the government's "hired scribblers", ${ }^{27}$ for 3501 a year. The newly founded Times, which was taking a 3001 subsidy from Pitt, continued nevertheless to claim the moral high-ground, printing: "What a pity a German upstart cannot purchase reputations, as well as corrupt newspapers!"28

With the outbreak of the American War of Independence satire and criticism of the political order merged with ominous warnings. Wardroper wrote:

From the City of London there came a new remonstrance....

We desire to repeat again that the power contended for in the colonies, under the specious name of dignity, is to all intents and purposes despotism: that the exercise of a despotic power in any part of the empire is inconsistent with the character and safety of this country...

Trade would be ruined, taxes would go up, and there was "nothing now to expect from America but gazettes of blood".

\footnotetext{
${ }^{24}$ Ibid 56.

${ }^{25}$ Ibid 57.

${ }^{26}$ Ibid 77.

${ }^{27}$ Ibid 129 .

${ }^{28}$ Ibid.
} 
If anything could add to the alarm of these events, it is Your Majesty's having declared your confidence in the wisdom of men, the majority of whom are notoriously bribed to betray their constituents and their country. ${ }^{29}$

At Christmas 1769 the Public Advertiser printed a letter by the mysterious Junius, a freelance writer, as follows:

Junius dares to warn the king that he may involve his country in "a fateful struggle”. To whom can he turn if his English people rebel? The Irish "have been uniformly plundered and oppressed". The Americans "consider you as united with your servants against America, and know how to distinguish the sovereign and a venal parliament on one side, from the real sentiments of the English people on the other"30.

In 1777 Horne Took was fined and sentenced to a year's imprisonment by Lord Mansfield for having made an announcement that the Constitutional Society was collecting for:

The relief of the widows, orphans and aged parents of our beloved American fellow-subjects, who, faithful to the character of Englishmen, preferring death to slavery, were for that reason only, inhumanely murdered by the King's troops at or near Lexington and Concord. ${ }^{31}$

\section{Wilkes v Wood}

It is then within the context of a highly politically engaged public that Wilkes $V$ Wood, the case which the Court in Boyd saw as formative of the Fourth Amendment, came before Pratt CJ, the English Chief Justice. Moreover, a significant portion of the English public were very critical the fusion between the of power of the Crown and economic suppression of their American "cousins" by the rising class of mercantile capitalists.

As stated by the Court in Boyd, the facts in Wilkes $v$ Wood were:

Certain numbers of the North Briton, particularly No. 45, had been very bold and in denunciation of the government, and were esteemed heinously libellous. By authority of the secretary's warrant, Wilkes' house was searched, and his papers were indiscriminately seized. For this outrage, he sued the perpetrators and obtained a verdict... ${ }^{32}$

In Wilkes $v$ Wood counsel for Wilkes submitted:

That if the warrants were once found to be legal, it would fling our liberties into a very unequal balance. ${ }^{33}$

In Wilkes $\mathrm{V}$ Wood it is recorded that:

${ }^{29}$ Ibid 82.

${ }^{30}$ Ibid 58.

${ }^{31}$ Ibid 88.

${ }^{32}$ Op. cit. Boyd 626.

${ }^{33}$ Wilkes $v$ Wood. 
Mr Eyre, the Recorder of London, then stood up: he apologized to the Bench for appearing in the present cause, considering the office he bore, but that he thought it was a cause which affected the liberty of every individual. Mr Eyre argued that:

No precedents, no legal determinations, not an Act of Parliament itself, is sufficient to warrant any proceeding contrary to the spirit of the constitution.

Mr Eyre also argued that "Nothing can be more unjust in itself, than that the proof of a man's guilt shall be extracted from his own bosom". ${ }^{34}$

In Wilkes $v$ Wood Pratt CJ held:

The defendants claimed a right, under precedents, to force persons houses, break open escrutores, seize their papers, etc. upon a general warrant, where no inventory is made of the things thus taken away, and where no offenders names are specified in the warrant, and therefore a discretionary power given to the messengers to search wherever their suspicions may chance to fall. If such a power is truly invested in a Secretary of State, and he can delegate this power, it certainly may affect the person and property of every man in this kingdom, and is totally subversive of the liberty of the subject. ${ }^{35}$

As the Supreme Court in Boyd saw, there is a direct connection between the right claimed by the Crown defendants here, that of the broad scope of the general warrant and "the obnoxious writs of assistance" as referred to by Justice Bradley in Boyd. In Wilkes $v$ Wood Pratt CJ further held that:

It is my opinion [that] the office precedents, which had been produced since the Revolution, are no justification of a practice in itself illegal, and contrary to the fundamental principles of the constitution; though its having been the constant practice of the office, might fairly be pleaded in mitigation of damages. ${ }^{36}$

Pratt CJ stated that:

He was satisfied the jury would not view Mr. Wilkes as not entitled to a verdict, because ... the case was a wound given to the constitution, and demanded damages accordingly.

\section{Entick v Carrington}

Wilkes $v$ Wood was one of a raft of cases in which Pratt CJ curbed King George III Administration's repression of critics of parliamentary corruption, by the award of ever increasing damages. The first of this series of cases was Entick $v$ Carrington, which is discussed at length below, as it is the lead case. In Entick 4001 together with costs was awarded and in Huckle $v$ Money 300 I was awarded. 
Following these cases 4001 was awarded in Money $v$ Leach and in Wilkes $V$ $W_{o o d}{ }^{37}$ itself, 10001 was awarded, a similar amount being given in Beardmore $V$ Carrington. In Wilkes $v$ Wood Pratt CJ, reiterating his stance on damages in Entick, held:

Notwithstanding what Mr. Solicitor-General has said, I have formerly delivered it as my opinion on another occasion, and I still continue of the same mind, that a jury have it in their power to give damages for more than the injury received. Damages are designed not only as a satisfaction to the injured person, but likewise as a punishment to the guilty, to deter from any such proceeding for the future, and as a proof of the detestation of the jury to the action itself. ${ }^{38}$

Subsequently, in Wilkes $v$ Halifax, the huge sum of 40001 was awarded. Four thousand guineas in the mid- $18^{\text {th }}$ century was equal to the yearly pension (above a 10,0001 settlement) that the King offered his brother's commoner wife to "renounce the title of duchess". ${ }^{39}$ Although it is not a simple matter to relate the value of 4000 guineas in 1769 to today's money arguably the most appropriate measure is "economic status", the value of which in 2014 amounted to roughly US\$13,000,000.

Entick $v$ Carrington is known as one of the "Great Cases" and is seen as foundational to the Fourth Amendment. Before delving into the details some general points of interest warrant mentioning. First it is instructive as to the extent to which rights have been incrementally eroded by the incessant pressure of the Executive, Pratt CJ noting that at common law there was no power to enter and search private property, for any reason, as follows:

The practice of searching for stolen goods crept into the law by imperceptible practice. It is not the only case of the kind that is to be met with. No less a person than my Lord Coke denied its legality... ${ }^{40}$

Secondly the case demonstrates that in protecting their own interests Administrations generally purport to act in the interest of national security, in Entick $V$ Carrington the Secretary of State declared; "All private mischiefs must be borne with patience, for preventing a national calamity" ${ }^{41}$

Thirdly the case shows that there is nothing new under the sun. In refuting previous judicial authority, for the lawfulness of general warrants, Justice Camden gave an instance of the breath of the previous determinations, as follows:

First, that it was criminal at common law, not only to write public seditious papers and false news; but likewise to publish any news without a license from the king, though it was true and innocent. (emphasis added) ... ${ }^{42}$ 
The case of Entick v Carrington arose because not only was John Wilkes himself targeted by King George III's Administration but in addition suspected publishers of his articles had their homes raided and searched. Wilkes had written a critique of the then Prime Minister, Lord Bute, in an article thinly veiled as a historical essay about Sejanus, the Emperor Tiberius' notorious aide. The article was printed in the Monitor, a radical newspaper published by John Entick. John Entick, along with Dr Shebbeare and Mr. Beardmore, was named in a "voluntary information" given to Lord Halifax by Jonathan Scott, a London bookseller, as one of those who had established The Monitor. Particularly mentioned in the information was the "Sejanus" issue, of which Scott stated, "I apprehend the character of Sejanus meant Lord Bute" ${ }^{43}$. Lord Halifax issued a general warrant for the search of Entick's home and the seizure of documents. The warrant was executed by a Kings Messenger, Nathan Carrington and read in part:

George Montagu Dunk, Earl of Halifax, Viscount Sunbury, and Baron Halifax, one of the Lords of His Majesty's Honourable Privy Council, Lieutenant-General of his Majesty's Forces, Lord Lieutenant-General and General of the Kingdom of Ireland, and principle Secretary of State \&c. These are in his Majesty's name to authorise and require you, taking a constable to your assistance, to make strict and diligent search for John Entick, the author or one concerned in the writing of several weekly very seditious papers, entitled The Monitor, or British Freeholder, No. 357, 358, 360, 373,376,378, 379 and 380; London, printed for J. Wilson and J. Fell in Paternoster-Row which contain gross and scandalous reflections and invectives upon His Majesty's government and upon both Houses of Parliament... ${ }^{44}$

After the search of his home John Entick bought a civil case of trespass brought against Carrington, alleging that Carrington and three others:

with force of arms broke and entered ... [Entick's] .. dwelling house .. and continued there four hours without his consent and against his will ... disturbed him in the peaceable possession thereof, and broke open the doors to the rooms ... and broke open the boxes, chests, drawers, \&c ... and searched and examined all the rooms, ... and read over, pryed into, and examined all the private papers ... whereby the secret affairs, \&c of the plaintiff became wrongfully discovered and made public; and took and carried away 100 printed charts, 100 printed pamphlets, ... to the damage of the plaintiff $2000 l^{45}$

Backed by the Administration, Carrington defended the case, maintaining that:

At the time of the supposed trespass, the Earl of Halifax was, and yet is one of the lords of the King's Privy Council, and one of his principal Secretaries

\footnotetext{
${ }^{43}$ Ibid.

${ }^{44}$ Ibid 810

${ }^{45}$ Ibid.
} 
of State, and that the earl, ... made his warrant under his hand and seal directed to the defendants, by which the earl did in the King's name authorise and require the defendants ... to make strict and diligent search for the plaintiff. ${ }^{46}$

Carrington's defence was mounted on the following primary grounds:

1) That pursuant 24 Geo. 2, c 44, the secretary of state had statutory power to issue the warrant;

2) As secretary of state and a privy counsellor the earl of Halifax had lawful power to issue the warrant;

3) At common-law the secretary of state could issue the warrant, as such warrants were an established legal practice which had been often employed since the Glorious Revolution, without judicial opposition. ${ }^{47}$

In regard to point (1) and statutory authority Pratt $\mathrm{CJ}$ noted that "the best way to construe modern statutes is to follow the words thereof", ${ }^{48}$ and after analysis concluded that the Secretary failed to come within the statute.

In regard to point (2) and whether such a power attaching to the offices the Earl of Halifax held, Pratt CJ differentiated between the judicial and executive functions thereof, and made a number of legal arguments finding:

As to the second. A power to issue such a warrant as this is contrary to the genius of the law of England; and even if they had found what they searched for, they could not have justified under it. But they did not find what they searched for, nor does it appear that the plaintiff was the author of any of the supposed seditious papers mentioned in the warrant; so that it now appears that this enormous trespass and violent proceeding has been done upon mere surmise. But the verdict says, such warrants have been granted by secretaries since the Revolution. If they have, it is high time to put an end to them; for if they are held to be legal, the liberty of this country is at an end. It is the publishing of a libel which is the crime, and not the having of it locked up in a private drawer in a man's study. But if having it in one's custody was the crime, no power can lawfully break into a man's house and study to search for evidence against him. This would be worse than the Spanish inquisition; for ransacking a man's secret drawers and boxes, to come at evidence against him, is like racking his body to come at his secret thoughts. The warrant is to seize all the plaintiff's books and papers without exception, and carry them before lord Halifax. What? Has a secretary of state a right to see all a man's private letters of correspondence, family concerns, trade and business? This would be monstrous indeed! And if it were lawful, no man could endure to live in this country. ${ }^{49}$

In buttressing this position Pratt CJ referenced core constitutional documents and institutions, stating that:

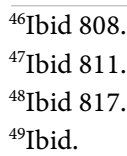


"if the Secretary of State had claimed any such power, then certainly the Petition of Right would have taken notice of it". ${ }^{50}$

And

"it is strange that House of Commons should take no notice of the Secretary of State, if he then had claimed power to commit." ${ }^{51}$

Emphasising the significance of the issues in play, Pratt CJ recalled Lord Coke's remonstrance "to the King that no subject ought to be committed by a Privy Counsellor against the law of the realm". ${ }^{52}$ The referencing of Lord Coke, the Petition of Right and the House of Commons is a direct reference the English Civil War. These are fighting words.

In regard to the third defence, that of common law decisions validating general warrants issued by the Secretary of State this appeal to judicial recognition of general warrants posed a serious threat to the tradition-based law upon which Pratt CJ relied on. As instanced above, Pratt CJ set out the very broad extent of the powers these decisions ratified and held:

There is no authority but of the Judges of that time that a house may be searched for a libel, but the twelve Judges cannot make law; and if a man is punishable for having a libel in his private custody, as in many cases he is, half the kingdom would be guilty in the case of a favourable libel, if libels may be searched for and seized by whomsoever and wheresoever as the Secretary of State thinks fit. ${ }^{53}$

In the above passage Pratt $\mathrm{CJ}$ made two key points. The first is that judges do not make the law, the law is a set of principles, not the determinations of judges. In regard to the latter part of the passage the word "libel" at that time could just mean a book or pamphlet, hence it may be a "favourable libel". Here Pratt CJ is making the overreach argument, that the power claimed is simply too broad. Also in utilising the language of "whomsoever and wheresoever" Pratt CJ is pointing to the arbitrariness of the power claimed. When considering the usage of such warrants since the turn of the century Pratt CJ held that:

it is too modern to be law; the common law did not begin with the Revolution; the ancient constitution which had been almost overthrown and destroyed, was then repaired and revived; the Revolution added a new buttress to the ancient venerable edifice. ${ }^{54}$

Of note is that when analysing the defendant's submission that comparing this general warrant with a judicial search warrant for stolen goods Pratt CJ notes that stolen goods belong to the person seeking the warrant, as was the process then, in contrast to the papers seized from John Entick, which were his property. One immediately sees a parallel with the position taken by the Court in Boyd, in

${ }^{54}$ Ibid.
} 
regards to forfeit goods, as set out above. In conclusion Pratt CJ held that:

our law holds the property of every man so sacred that no man can set his foot upon his neighbour's close without his leave; if he does he is a trespasser, though he does no damage at all; if he will tread upon his neighbour's ground he must justify it by law... we can safely say there is no law in this country to justify the defendants in what they have done; if there was, it would destroy all the comforts of society; for papers are often the dearest property a man can have. ${ }^{55}$

Property rights are constitutional rights as property provides a degree of autonomy vis a vis state power. Without autonomy there can be little or no liberty. Pratt CJ says that the law accords great significance to property rights, trespass against which must be justified by law. He then says that the defendants failed to justify their actions. This is all he needs to say but Pratt CJ goes on to say that if the law permitted such actions "it would destroy all the comforts of society". The phrase "destroy all the comforts of society" raises the constitutional issue that a nation's constitution, like an individual's, is about flourishing and in the case of a nation this is achieved by social organisation. However, the English Constitution, in its maxim that "no power is unfettered", also recognised that the power generated and concentrated by social organisation, if uncontrolled, could lead to the destruction of society, rather than its betterment. It is also probably not coincidence that Pratt CJ had used the same word "destroy" in the above phrase as well as in the comment about the "ancient constitution which had been almost overthrown and destroyed". Here Pratt CJ is referring to the attempt by the Stuarts to overthrow the English Constitution, with its balance of power and rule absolutely. The destruction of "all the comforts of society" puts into issue the very fabric of society itself and raises the alternatives of absolutism or civil war.

\section{Conclusion}

The thesis in this paper is that there is a lineage which stretches from the English "Ancient Constitution"; to use Blackstone's term, through the "Great Cases" of Entick $v$ Carrington and Wilkes $v$ Wood, to the Fourth Amendment, as upheld in Boyd. This lineage demonstrates that properly, the law of search and seizure has nothing to do with the puny interest of person privacy and everything to do with public security against the misuse of power. Blackstone said of the Ancient Constitution that it had been gnawed at by rats and he was not referring to rodents. The rats have been busy since and the conceptualisation of the social value underlying search and seizure as one of personal privacy has all but gnawed through the bonds of law, which once constrained violations by unreasonable searches and seizures.

The law of search and seizure delineates a crucial boundary between the power of the state and freedom within society. The history of this law shows a continual pressure by the state to increase its power, punctuated by resistance, such ${ }^{55}$ Ibid 818. 
as the Great Cases discussed above and the creation of the Fourth Amendment of the Constitution of the United States, which have rolled back arbitrary power and restated the freedoms found in the English "Ancient Constitution". Freedom, as the word suggests, is a dominion, free of the domination of others. As such it is a terrain outside the province of the powerful. Statements of this right, such as the Fourth Amendment, speak of the "right of the people to be secure" (emphasis added) and of violation. Security denotes absence of threat and violation. The threat of violation at issue is the threat of arbitrary power, as the historical discourse clearly shows.

The elevation of privacy, as the value which is the basis for the Fourth Amendment, reduces the right's foundation from being a matter of public interest to that of a personal interest. The interpretation of a right to be secure as a right to privacy reduces the value of that right, as security is more important than privacy. Privacy is a puny interest which will always be reduced to a right to shield wrong and as such it will be weighed against public interest and found wanting. The public interest in restraining the power of the State and the entire constitutional discourse, so explicit in Boyd and the English cases, is completely absent in Katz. The result is that the bonds of law are loosened and the danger arises that power may become arbitrary.

\section{Conflicts of Interest}

The author declares no conflicts of interest regarding the publication of this paper.

\section{References}

Beardmore v Carrington (1764). 2 Wils KB 244.

Bonnard v Perryman (1891). 2 Ch. 269; 283.

Boyd v. United States (1886). 116 U.S. 616.

Entick v Carrington (1765). 19 State Tr 1029; 95 ER 807: 809.

Hester v. United States (1924). 265 U.S. 57.

Huckle v Money (1763). 2 Wils 205.

Katz v. United States (1967). 389 U.S. 347.

Money v Leach (1765). 3 Burr. 1692, 1742, 19 S.T. 1002.

Olmstead v United States (1924). 265 U.S. 57.

Semaynes Case. All ER Rep 625 Co Rep 91 a Cro Eliz 908 Moore KB 668 Yelv 2977 ER 194.

United States v. Jones (2012). 565 U.S. 400.

Wardroper, J. (1973). Kings, Lords and Wicked Libellers.

Wilkes v Halifax (1769). 19 S.T. 1406.

Wilkes v Wood (1763). 2 Wils. KB 203, 204, Lofft 1, 19 S.T. 1153.

Writ of Assistance Case or Paxton's Case. Court Files Suffolk Vol. 572 March 1765 No 100.5156 Application Merchants 19 Jan 1761. 